\title{
FROM MOVEMENT TO MANAGEMENT: Aboriginal assertion, government and environmentalist responses and some ways forward regarding conservation and social justice
}

\section{Transforming Cultures eJ ournal, \\ Vol. 3 No 1, February 2008 http:// epress.lib.uts.edu.au/journals/TfC}

\section{Peter Thompson}

Interviewed by Heather Goodall, ${ }^{1} 25$ Jan 2007.

\section{Aboriginal conservation interests in context}

Heather Goodall: You've been working with Aboriginal people and been part of their extended communities in the north western and western areas of the state for over 40 years now. But you're in an unusual position because as a resident of country towns you've also been involved in local environmental campaigns over rivers and protecting native vegetation and you take part in state-wide conservation organizations like the Nature Conservation Council.

I wanted to hear how you see the interactions between land rights and conservation and social justice. Can you talk about your work with Aboriginal people over conservation reserves in NSW. You were involved early on in the campaign for ownership of the national park at Mutawintji in the far west of the state and more recently in relation to the new community conservation areas around Terry Hie Hie on the northwestern slopes.

\footnotetext{
${ }^{1}$ Heather Goodall has worked in collaboration with Indigenous people in NSW and in Central Australia on political, social and environmental history. Her research in each area has followed the ways in which Indigenous people's interests in active land relationships have been expressed in campaigns for land rights and in various land management outcomes, from common land to Aboriginal land rights and native title and to protected areas and national parks.
} 
Do you see Aboriginal people as successfully establishing their interests in land through conservation areas? Have the arrangements for, say, joint management of national parks, emerging in the late 1980s, been a step towards social justice?

Peter Thompson: Well the first of these campaigns was for the Aboriginal ownership of Mutawintji National Park but it began as an integral part of political actions for land rights in a State-wide campaign from the mid 1970s to gain land rights legislation. In the western areas, a series of bush meetings were held by Wiimpatja, the local Aboriginal people, which basically meant that people got out of towns, away from halls and formal meeting structures. They camped out, had large wide ranging meetings in the bush itself, caught, gathered and ate bush tucker and at night they sat around campfires. Everyone had yarns and funny stories to tell, and they all heard as well the stories from the old people who came out with us about their lives working on the stations and droving in the past, as well as their knowledge about the traditional stories of the lands there. All this allowed Wiimpatja to clarify their collective aspirations for the all-too-often vague call for 'land rights now'. There were some clear goals which emerged: getting large areas of land returned by purchasing grazing properties; protecting cultural places; and access to all land for hunting, fishing, gathering and visiting sites. There was agreement for local ownership and control, and regional organisation and support.

The fact that this was a political campaign provided a situation where it was both important and possible for the Aboriginal people involved to work on their relationships. Wiimpatja had set the agenda. It was a liberating and a decolonising experience. They were responsible and they had to sort out any problems. No one else would. These principles were applied to the Mutawintji campaign.

That really got going in 1983. Aboriginal people had been worried about how Mutawintji was being looked after for years, but these bush meetings had allowed people to focus that concern in action. Mutawintji is an important place for many reasons but it had been pastoral property for a long time, around a group of low ranges, and most of the Aboriginal people related to it have been living at a distance, in either Wilcannia, Broken Hill or other towns. But they 
came together in 1983 and with supporters, these Wiimpatja blockaded the Park entrance during the centenary celebrations of the nearby mining town of Broken Hill. They put up signs saying 'Mootawingee, Closed by the Owners'2 and turned the tourist buses back to town, but not before talking with the passengers about why they were undertaking the blockade. For Wiimpatja, the National Park wasn't just a tourist attraction: it is a place of sacred water holes, creation stories, ceremonies, ancient art sites and spiritual strength for them and the broader community of western NSW.

\section{Shifting the paradigm from sites to country}

Heather: You've talked about Aboriginal people setting the agenda, the terms of reference, in the overall campaigns. During the land rights campaign, there were lots of ideas about the state of the countryside, how did people see the land condition in that period?

Peter: I suppose there were mixed feelings, not so much between different people as just within any person. Many of the people who have been active in that land rights campaign have grown up working on sheep and cattle properties. That was an important period in their life and an important motivation for why they might want to get land back. But that was mixed with the feeling that some places needed to be looked after. I had been living within the Aboriginal community there for some years by then and from talking around, I suspect that although no one was particularly clear about it, it was just taken for granted that some places had been flogged by sheep and cattle. What was consciously expressed was that the land had been abused and misused and so these places needed looking after.

Heather: The Mutawintji National Park itself has got such a focus on the sites, the artworks and the landforms and things that it's not quite the same broad-acre management question. Even though it includes areas

\footnotetext{
2 The colonial spelling 'Mootwingee' was changed by the blockaders to 'Mootawingee' to better represent the Wiimpatja pronunciation. It is now spelt 'Mutawintji' (still pronounced with the 'oo' vowel) using the spelling system developed by the Wilcannia language program.
} 
that were once a grazing property, it wasn't expected to be a productive area or an economic resource was it, apart from tourism?

Peter: It certainly wasn't proposed to use it for grazing sheep or cattle. But I don't think it was based on a distinction between production and conservation. I just think that people had an attitude that encompassed the value of land that was over and above that dichotomy of having to make that choice.

Heather: Is the idea of separating conservation and production a fairly recent idea about a dichotomy that's got wilderness on the one hand and...?

Peter: People were saying that not grazing didn't mean that the land wasn't being productive. They were saying that 'we'll assume that this is not going to be productive in any of the normal senses of the words used. So we won't discuss whether we've got a dichotomy or not.' It would come up now and again. There's a famous occasion that William Bates, one of the blockade's key Wiimpatja organizers, likes to talk about. It was the meeting where his old father, Jim Bates said "What this Mutawintji needs is a thousand head of cattle."

Heather: ...and?

Peter: $\quad$...and everybody laughed!

Although if Aboriginal people got land back they would aspire to use it. They'd also aspire to look after it!

One of the interesting things about the Mutawintji experience was that it did involve shifting a paradigm. That paradigm was that the National Parks Service manages National Parks - and they will only talk to Aboriginal people about how to manage the Aboriginal sites inside the parks. But here you had a group of people who were saying "Look, we're not talking to you about managing sites, we're talking to you about managing the country."

That was quite a culture shift for the National Parks Service to make. Or try to make, they may not have succeeded yet, but... 
Heather: It helps to make a lot more sense about what happened afterwards, in general, to recognize that this was a very different idea than the old approach of managing specific sites.

Peter: $\quad$ Yeah, I think that as Aboriginal people made their voices heard on a lot of subjects through the '70's and into the ' 80 's, the usual government response was to say, "Well this is how we'll deal with that, we'll pigeon hole people and we'll deal with their little concerns about little aspects of the business of government and yeah, okay, we can accept the proposition that we should talk to Aboriginal people about burial or sacred sites whatever they might be or perhaps even stone artefacts. But that's it! That's as far as our legislative responsibility goes.” In fact from the government's point of view, it's still about objects, and sites! But in the context of the land rights movement, what was happening in Western New South Wales was that the key goals for Wiimpatja were to get big areas of land back and to continue culture and to have access to all the rest of the land. This has become so common since then that it's almost jargon nowadays but it wasn't used then. The way the National Parks Service and the conservation movement talked in those days, conservation of the landscape was a white aspiration. So we just were completely overturning the previous ghetto-isation of Aboriginal interests which had been seen by the government as limited to the pinpoints on maps that they called 'sites'.

The Mutawintji movement was part of forcing that paradigm shift. And it's still shifting, it's not there yet by any means. And, some things in other places may even have re-ghetto-ised it, if anything. Pipelines and electricity power lines and the site surveys around those particular things have focused in people's attention down again onto the points, rather than country. Like by making a big fuss about a pipeline going through, while all around it, hundreds of thousands of hectares have been cleared or changed from grazing or farming to irrigation, say in a district like Moree. So the whole landscape is being transformed and ruined. Yet Aboriginal people are being 'trained' to focus on a few points or a few corridors and not to think about the cultural values being threatened by that broader change. 


\section{The Handover: promises and frustrations:}

Heather: As I understand it, after 13 years of campaigning and negotiating, NSW State legislation enabling Aboriginal ownership of National Parks was finally passed in 1996. The new law provided for a joint management structure under a Board with a majority of traditional owners. Then two years later, in 1998, I remember being there when the 76,000 hectare Mutawintji National Park was handed back to the traditional owners. One of the advantages of that sort of 'handback' of an existing park I suppose is that you've got the infrastructure of the park all there in place as well as the recognition that its not going to be used for commercial purposes. Was that seen as a benefit?

Peter: Yes and no - it did mean the whole thing seemed quick to get off the ground. But in another way, there was a problem because there was already an entrenched National Parks Service structure there which made the public servants and the government feel that they owned it - and so there were resistances to changing the way things were managed.

Heather: One of the things I know that you've pointed out is that the 1983 Land Rights Act was being dismantled in 1991 with amendments which destroyed the Aboriginal-controlled regional structures which had supported local communities. Changes to the land rights act centralized the ownership and control of land. These changes wiped out inalienable title, so land became saleable which undermined confidence, sustained ownership and even undermined interest in purchase of land. So just as the campaign for Aboriginal ownership in national parks was really getting support in the government, you've got the Land Rights Act itself being you know gutted. Did this make the local ownership of National Parks like Mutawintji so much more important?

Peter: $\quad$ Yeah, that's right. The people involved with Mutawintji had set up a Local Aboriginal Land Council, and that has continued to be a key place for 
talking through the issues, but they'd received important support from the Western Regional Aboriginal Land Council, involving people from all the different communities along the river and in the far west. It was a real problem that the Regional Land Council was essentially dismantled after the 1991 amendments to the Land Rights Act.

Heather: This National Parks legislation forced compulsory joint management with the state, even though Aboriginal people owned the land. But it actually gave majority control on the Mutawintji Board of Management to Aboriginal people, didn't it? They've got majority voting control on it. Did that offer an empowering avenue for Wiimpatja?

Peter: This legislative scheme of ownership and compulsory leaseback has been criticised as being less than full ownership and control and that is of course true. But Australian law had no better options then for asserting land rights over a National Park. Negotiations ensured that the Mutawintji lease achieved the most possible within this progressive enabling legislation. There's potential for lots of dynamics there and that's good I suppose, but you know the Board is subject to what sort of advice it gets and what sort of deliberation it makes. The overall effect so far has been great frustration for Aboriginal Board members and there are some key reasons that we can talk about. I believe that the legislation supports empowerment. But the residual power of bureaucracy was never addressed and so it has found other ways to exercise itself.

This can have the effect that it can drive the Board back into stubbornness or underdog mentality or closing its mind to advice because mistrust is the key element. Here we got a system that very clearly places power with the Board. The Act says that the Board has the position of the Director General in relation to this park as having care, control and management. Yet the outcome so far has been frustration rather than empowerment.

\section{Lets look at why. (1) Rent - what is it and how is it used?}

Heather: What do you think the reasons have been for that frustration? 
Peter: I think we can usefully focus on two key issues. One of them is rent, and it highlights the very different understandings of the structure set up by the legislation depending on whether you look at it from the Aboriginal point of view or from the point of view of the National Parks Service. The other issue is the ongoing failure to implement Board decisions and it highlights the huge problem of the power for implementation resting outside the Board's control.

When we were in negotiations about the terms of the lease, what we wanted to ensure was that the rent didn't become a substitute for normal budgetary commitment. In the view of the Aboriginal community, the core business of running Mutawintji National Park should be funded from a normal budget commitment. The rent should add something special.

Remember that it was a big struggle within the government to get rent included in the ownership legislation. Apparently this struggle continues. I have heard that there are people within DECC right now talking up the idea of removing rent from the Act. Its like any struggle won to treat Aboriginal people with normal decency: it is always in danger of being undermined.

The Act made the purpose of the rent just a bit vague. It's clear that it is a specific, negotiated amount of real money: it was set in 1998 that the Handback rent is $\$ 275,000$ a year, indexed to inflation. That means it is now up to $\$ 340,000$. It gets paid to the Board by Treasury in advance each financial year, into a special fund, held as part of the National Parks and Wildlife Fund which is a statutory account with Treasury. That means it is put somewhere securely for the use of Mutawintji and only Mutawintji.

Now the Act says the rent is to be an amount that compensates the Land Council for not having full use and enjoyment of its land. So that's an interesting concept, and we've interpreted that as needing to have an element of compensation, or community development or increasing Aboriginal involvement. The other thing it says is that the rent has to be used for the management of the Park, so you've got this two part test and they both sounded a bit different, almost in conflict. But our approach has been just to apply those two parts. So the rent is there as an extra bucket of money. This makes it very tempting to use for things that would be paid for in other ways if this wasn't an Aboriginal owned park. This couldn't be quite tied down enough during the 
lease negotiations and so it remains an issue that people have to be vigilant about or it will get diverted.

The early Board meetings decided on a notional break for use of the rent. The original $\$ 275,000$ was divided into three sections: $\$ 120,000$ for community development projects, $\$ 120,000$ to go into a fund for purchasing land to add to the park and \$35,000 for what they called seeding money, that could be used for things that were fairly normal national park management, as long as other extra money was attracted by the use of that seeding money.

This rent doesn't have to be used within any one financial year, there's no penalty for that. William Bates, when he was chairperson of the Board, negotiated early on that the interest earned on the money in the rent account that was not used, so would also be credited to this special safe account. And Treasury hated that because that's how government makes some of it's money, by drawing back interest and resuming unspent money. They regard it as their money, yeah. But William insisted and eventually Treasury agreed.

However, when the interest started coming in, the Parks Service senior staff member, who was on the board of the time, just set up a fourth account with the interest in it. So that made four categories. Instead of distributing the interest notionally over those three original categories, this sleight of hand established the fourth one which began to be used as a bit of a slush fund for things that should have been paid for under normal park management or for the cost of running the Board, which is a core function that should be paid for by normal park management funds as well.

Just by attrition or political drift, the process was adopted of using the wrong language about money. It began to be said that the rent was the Board's money and all the rest was the National Park Service's money. In fact $A L L$ the money is the Board's money, it just comes from several sources: one is rent, one is recurrent funding for salaries, one is recurrent funding for management costs, one is capital expenditure, one might be income earned on the park, another one might be special grants that all other parks get access to, and another one might be external funding, Commonwealth or whatever. So all these monies are the Board's money, but unfortunately language has been adopted that reinforces the idea that the rent is the Board's money and all the rest of it is the Park Service's money. 
So the Board has had to be vigilant to see that the rent money is used in the way it should be, not as if it were part of recurrent funding for the Park's normal management.

\section{Lets look at why. (2) Implementation - the Board's decisions ignored Heather: And the other key issue?}

Peter: The main constraint on the success of the Board is how enthusiastically its decisions of the board are implemented and the power to do so is out of its hands. It has to rely on the National Parks and Wildlife Service, now part of DECC $^{3}$, to implement its decisions. It's a factor that can have powerful feedback on the functioning of the Board. The negative feedback that happens because the Board's decisions haven't been implemented can go so far as to affect the Board's conscientiousness about its duties. It can just get into an underdog and blaming situation.

\section{Heather: What sort of decisions haven't been implemented?}

Peter: $\quad$ First I have to say that the government eventually admitted it was doing the wrong thing and is now committed to doing better. But a lot of damage was done and it will take a while for a good relationship to be built.

This failure to implement Board decisions was a sustained pattern from the earliest days but I'll just give three examples here. The Board inherited some difficult problems from the pre-handback days which NPWS just didn't fix, despite the Aboriginal negotiators demanding that these loose ends had to be resolved before handover. One of them had been the appointment of the only Ranger for Mutawintji who was allowed to live in Broken Hill instead of living on the park. This was a clearly unsatisfactory situation which the Board thought wasn't giving adequate service to the Park. The other was a neighbouring landholder who had property on both sides of the National Park and who had been for a long time moving his sheep across the National Park, and in fact through an area which was declared wilderness. Again, the incoming Board

\footnotetext{
${ }^{3}$ Department of Environment and Climate Change.
} 
members expressed clear disapproval of this situation before the handback. In fact it is not lawful for the grazier to do it and not lawful for the Park Manager to give permission for it to happen. When the Board took over, and found these two problems still happening, it tried to get them changed, it moved all the right resolutions and then it was just ignored. The Chairperson of the Board wrote formal letters to the Director General of the Department, explaining that its decisions hadn't been implemented and seeking to set up a dispute resolution process, but no answer, no news, nothing!

A third example was about money to pay for the position of Joint Management Coordinator. This role was modeled on a similar position at Uluru National Park, one of the first to have Aboriginal ownership and then be jointly managed. The central duty of this person was to make sure the decisions of the Board got implemented. This was difficult enough, as I've been explaining, and the position had a chequered history, but the point here is that it was rightly paid for from the normal recurrent budget of the Park. Then, after about three years, a decision was taken within the Parks Service to draw the funding for this position from Mutawintji rent account. This was not a decision of the Board and so the Board tried to resolve the problem through the formal dispute process with the Parks Service. As I said, the Board was ignored, and you can imagine how that demoralized the Aboriginal members and especially angered the Chairman. These three disputes have all lingered on for years. In the case of the ranger, it was eventually resolved by the resignation of the non-resident officer, rather than by any action on the part of the Parks Service. And its only now after three or four years that the Parks Service has accepted that the normal park budget would pay for the Joint Management Coordinator for the next three years but even then they have asked that it be alternated, actually that they go halves in this, between the rent and the normal budget. And the other one about the neighbour is unresolved. So things like that are really the nuts and bolts of demoralisation of the Board.

\section{Grappling with conservation questions: watering points}

Heather: Since the board was established in '98, have there been issues that have emerged about regenerating the damaged area that was 
pastoral property? Problems which would be viewed more from outside as issues of biological conservation, as opposed to those more directly about cultural rights or empowerment? I'm assuming that the Board might not be making that distinction, but how are they approaching the question of restoration or protection of the environment of the Parklands?

Peter: There may not be any really big conservation issues to address at all. The fact that sheep and cattle have been removed is an incredible gain for conservation. I went to Mutawintji recently when it was very dry. The entire Park was very impressive. The other side was bare ground. In the park the ground was covered, held together by dead vegetation. A tremendous benefit in the worst of times. Otherwise, the park just runs, it just ticks along without there seeming to be an urgent issue. By and large it’s the Parks Service view that you don't have to do a lot more than that, you have to control weeds and feral animals.

But there are issues that the Board has been worried about. One of the reasons why it is struggling to deal with them is because of this whole history of conflict leading to mistrust and digging in over positions - that leads to a lack of deliberation of what's happening there. Now some of those issues are being worked on a bit, as people have been drafting new Plan of Management.

So one big conservation issue that's come up in the Board and this is the main issue generally in the far west of New South Wales, is vegetation degradation by grazing animals. And there’s disagreement amongst advisors and experts and Parks staff and locals about how to begin the process of restoration. I suppose I'm in the group of people that feels that there's too many artificial watering points in the landscape. Over the whole region this has elevated the number of large kangaroos and of course the feral goats that are in plague proportions across western New South Wales.

Rabbits are fairly well under control at the moment but vegetation can't recover while we've got plague proportions of feral goats that don't respect tenure boundaries and large numbers of kangaroos, in much larger numbers than they were two or three hundred years ago. We can remove sheep and cattle, but we've still got these problems that take deliberation and perhaps specific access 
to knowledge, maybe a bit of research. The Board is struggling to deal with this issue at the moment.

And they are difficult issues. It's like the problem of rabbits in Central Australia where some Aboriginal people say 'Oh we eat those animals, so we want to keep them'. So if an area in western NSW has got a ground tank there, it means there are lots of kangaroos, so people can have as swim or get a yabby or always know that they can get a kangaroo if they want one. This has been the experience for well over a hundred years, it's not as if anyone is alive who's got any memory of what it was like before this. The best way effectively to control large herbivores is with large carnivores, but bringing back the dingo is a bit of a no-no in western NSW. But watering points are the second most important way to do it and you can close them.

If we find a few small animals there that people value but which are now there in really low numbers, we can think about how they can be restored into high numbers. There has been a lot of success and strong Aboriginal support for saving the yellow-footed rock wallaby. It's only population in New South Wales occurs on the eastern edge of the reserve and it's got particular habitat requirements. Some of the only areas it can live in are in the national park and some are in the nature reserve, so they're all part of Mutawintji. Research has established that the main threat is probably foxes eating young ones and then the secondary threat is probably competition for food from goats and large kangaroos. So there has been a fair bit of goat control and quite an effective fox control program around the rock wallaby colony. Aboriginal people have been very strongly a part of that. The Mutawintji Board and its Aboriginal members see the rock wallaby as a bit of a mascot animal and symbolic of the park and they've been very keen to support its conservation. So that's a success story but the population of yellow footed rock wallabies recovered a bit then the drought come along and now it's gone back down and it still hasn't expanded it's range to other possible habitat sites. We know in general terms that fox numbers are higher near artificial waters and so too are large grazing animals. And areas around these artificial waters have less groundcover shelter for the small animals.

So getting the ground cover of vegetation back can have flow on effects to reduce predation risk, not just for the rock wallaby but for other small 
mammals and birds that use the ground layer. Both the fox and the feral cat, which is also a threat, are both fairly dependant on water. So maybe some more research will show that to close down watering points will be good for the rock wallaby.

Heather: My experience has been further up river along the Darling, north east towards the Culgoa and the Narran rivers on the floodplain. Take Rex Skuthorpe on Boda, that Aboriginal-owned property on the Narran. He talked with me about the way he was aware of pasture damage and landscape changes when he was working on properties as a stockman but it's really only been since he's been in the position of making decisions about the land as a manager of that property on behalf of the Goodooga community that he's been learning more about it and finding out about strategies for regeneration. Now he's become active in replanting native grasses and monitoring salt bush. He was reflecting on that process of learning, of having the luxury of a bit of breathing space to take in information and think about how you might actually have the power to change land management. Is there any of that type of conversation going on at Mutawintji?

Peter: Well there has been and there is, but I just think it isn't getting to the next step of action. And again there's probably two main reasons and one is that the Board isn't getting a good reception to some of its decisions, so that it's sort of pulling back from that sort of deliberation. The second one is that Aboriginal people need the chance to build up a strong relationship with staff who can offer some expertise. The National Parks staff, the scientific staff, the ranger and other Parks Service people who should be able to have an input into this, have only a relatively short term that they spend out there. Sometimes they don't know the area all that well when they come and so they're just on this little steep learning curve and then they're gone. With a lot of this stuff, people are interested and they want to know about it. And I would say they have a lot of knowledge about it as well, from their own working backgrounds and their observations as well as what they've been taught by their old people. But at the moment its difficult just keeping that building up so that it becomes conservation action. The sense of 
frustration is working against that openness to explore those areas about looking after damaged country. The urgent issues seem to be about managing to survive at the moment!

\section{More conservation questions: park boundaries [the implementation problem again]}

Heather: You've talked about the paradigm shift from sites to country which Aboriginal people have been forcing onto agencies like NPWS. How has this worked out in practice at Mutawintji?

Peter: $\quad$ This is an important issue about seeing the country beyond the limits of the borders of the national park. And it's another story here too about decisions of the Board being ignored. The Board made the decision at the very beginning to put a proportion of the rent aside each year to put towards expanding the park. We're just planning for good conservation. The reserve has a totally inadequate shape, where the ratio of edge to area is hopeless. There's a gap between the nature reserve and the national park where the rock wallabies are and the size just isn't quite adequate for conserving the ecosystems that are there. And there are some cultural sites just outside it, so there's a whole lot of reasons to want to expand it.

And the money is starting to build up. Now there's probably enough money there to buy a property and with matching federal funds and hopefully a little bit of money from the state for the boundary rationalisation issues, there's perhaps enough money to buy a couple of properties now.

So a couple of times since the handback the Board have said "Yeah, well let's do something about this. You know, we're starting to accumulate some money, we need to set up an arrangement and how about we put together a proposal and put it to the State Government and to the Federal Government that matches money for conservation acquisition.” And it has just always fallen on deaf ears.

So we're just trying to do it again now and hopefully we'll get it. It just wasn't done, you know, this is just another decision that never got implemented.

Heather: Why do you think it hasn't been pursued by the Department? 
Peter: Perhaps there's a reluctance to expand the National Park estate because of the extra management cost. The treasury is hitting people over the head constantly. It seems to us that the Park Service has gone off the boil in their attitude to acquisition of new lands. But far western NSW had a very low percentage of land in reserves, so the government should be supporting this expansion of the park area.

Heather: So it's an issue about the economics of management? All of the examples you are raising are about the cost of maintenance or other aspects of the practical implementation of programs in the park like taking action against the neighbour. The problems seem to be about a refusal to alter real financial and practical arrangements as one of the ways of not seriously acknowledging that the Board has a different agenda from that of the Park Service?

Peter: There certainly seems to have been a punitive approach where Aboriginal people have some hold on power in the actual management of parklands. There are a couple of other National Parks in the region under the Parks Service which aren't Aboriginal-owned and when you compare Mutawintji with these places there are some real questions about the way the Government has dealt with them. When you look at jobs which are all funded from the normal recurrent budget of the three parks, for example, the two other parks have been offered significantly more Wiimpatja employment than Mutawintji, which means they are being treated more favourably than Mutawintji. Lake Mungo, for instance, has 111,000 ha and now has 7 Wiimpatja jobs and the Paroo-Darling National Park, with 84,000 ha had 8 training jobs established for Wiimpatja. But Mutawintji, with 76,000 ha has only 3 Wiimpatja jobs. So there seems to be a pattern, which is that if you have real power under Aboriginal ownership then the budget will be tightened. Is this revenge? Or sabotage?

\section{Terry Hie Hie}

Heather: Can we talk now about one of the most recent park negotiations in which you've been involved. This has been the long but recently 
successful campaign by a community with whom you've also had a long involvement, the Terry Hie Hie Murris. These are Gamilaraay people who might now live in Moree or Boggabilla but whose families have had strong connections with the area round Terry Hie Hie on the northwest slopes of NSW. This has only just recently been declared a protected area for conservation purposes but is it a National Park? And is there a joint management arrangement in place?

Peter: The answer is 'no' for both of those questions! Murris have been trying to get the lands protected there for a long time. They've been trying to get tenure over the areas where they have a traditional link as well as having lived there on the Protection Board station they all called a 'mission' at Terry Hie Hie. But this new park doesn't really acknowledge that. It's listed in the Brigalow and Nandewar Community Conservation Area Act as seven separate areas with the status of 'Community Conservation Area Zone 2 for Conservation and Aboriginal Culture'. This also means they are reserved under the National Parks and Wildlife Act with the status of 'Aboriginal Area'. So the short answer is that they are an Aboriginal Area. But there is no joint management. The Brigalow and Nandewar Community Conservation Area Act 2005 actually states that it excludes Aboriginal ownership in the future, although this is not much more than a gratuitous insult because both the ownership status and this 'prohibition' could be altered by an amendment to the legislation.

This government decision not to agree to an Aboriginal-owned National Park at Terry Hie Hie was based on their opinion that there were too many problems at Mutawintji. And that opinion was based on the way the Parks Service has been sabotaging the success of the joint management process at Mutawintji. It's been bureaucratic racism in practice! Unfortunately there are still people in government trying to further undermine the principles of Aboriginal ownership and joint management of National Parks. Why is it so hard for governments to share a little bit of power with Aboriginal citizens?

Heather It looks like the Aboriginal community involved with Terry Hie Hie has been reflecting on what have been the issues and problems in other areas and trying to address those. A couple of things strike me. 
One is the very different organizational structure that Aboriginal people have set up, one that's separate from any 'Board of Management' that might develop in the future. And the second thing is the plan for an environmental recording and learning program that the Aboriginal community itself has set up for itself. Can you talk a little about each of those?

\section{Reworking structures}

Peter: The differences relate to the different situations that Aboriginal people face in each place, but there have also been a lot of lessons learnt I think over the last 20 years about ways to allow a community organization to run in a fair way that allows everyone in the community to have a say.

In the Terry Hie Hie parklands situation, there has been a real absence of government support to negotiate ownership and leaseback. So our strategy has been to propose a contract to the traditional owners' corporation to manage the park. The Terry Hie Hie Co-op Ltd is being established as the vehicle to take on this role. The next few years will be used to build capacity of the Co-op by taking on a range of small separate contracts to manage the park - such as fox baiting, erecting signs, neighbour liaison, fencing, site recording, weed control all the routine management normally done by NPWS. The mechanism will be through 'negotiated contracts' or 'preferred tender status' for the Co-op. One challenge will be to prevent NPWS building up its own staff numbers and so pre-empting the contract arrangement. That would just set up a situation like that at other National Parks where the Parks Service is seen as the 'normal' body to run things. The Co-op will share the work out as part-time and casual employment among its members and other skilled people as needed. Within a few years the aim is to have a 'global contract' to manage the park. Another option that might be explored is the lease of the park to the Co-op, like the situation of the Witjira National Park in South Australia. People have chosen to have a co-operative because it lets them work out rules that make sense for their goals of community control. This co-operative is out of the direct control of the Government. It draws on the long history of working class and community co-operative organisation around the world, but 
particularly on the work of Tranby Aboriginal Co-operative College and lots of co-ops in Aboriginal communities like nearby Toomelah and over on the coast at Cabbage Tree Island and Baryulgil. Basically, the rules of the Terry Hie Hie Coop are aimed at promoting culturally appropriate democracy, and these are rules developed from looking at what has and what hasn't worked in the experiences of Aboriginal community managed organizations of all sorts over the last twenty or thirty years. So the Terry Hie Hie Co-Op rules say that to maintain rights as an 'active member', a member must do 25 hours voluntary work for the co-op each year and pay $\$ 10$ subscription each year. Each of the nine directors is to be from a different family group with traditional family ties to Terry Hie Hie. No person can be a director at the same time as their brother or sister, husband or wife, parent or child. Both the directors' meetings and general meetings make decisions by consensus. Deadlocked issues can be adjourned and then passed with an $80 \%$ vote. These rules were developed at several public meetings in Moree with the aim of creating an organisation that encouraged people from all the different Terry Hie Hie Aboriginal families to work together in a fair way.

\section{Learning under Aboriginal control}

Heather: So where did the idea of these bush learning visits come from?

Peter: The environmental learning trips have been an initiative of the Co-op. We applied for some funding independently of the State National Parks Service and so this is funded with a little grant under the Commonwealth Government's Natural Heritage Trust grants to local organisations’ proposals. There was a part that was earmarked for Aboriginal people to hand on traditional knowledge about land management and so we put in a submission. The people that formed the Terry Hie Hie Co-op are hoping to take on a contract role in managing the new park there. We put together this submission and we were successful in getting $\$ 21,700$, to run this little program which will be a series of field trips where some people with knowledge will show teach anybody else who wants to learn. It will cross a lot of fields like bush tucker and cooking food; observing the tracks and traces of animals; site recording and maybe even the transitional skills like fencing; and there'll be local Gamilaraay language and art. 
So we'll have a series of mini field days, with maybe one or two teachers and a dozen learners or something like that, that's what's envisaged. And there's also allowance for collaboration, so if there's a plant thing on, we can get a botanist as well, that sort of thing. And we'll select those people so they won't be too bossy and take over. So that's what we are looking at and we hope to run that over the coming year.

So, that feeds a bit into building a bit of capacity for co-op members and other people that are interested to have a role in management, because the co-op will be negotiating for initially half a dozen small contracts to do different things, so it's manageable and not too scary and allows the co-op to build it's capacity to run those. In a couple of years, it will hopefully be evolving towards a single, global contract to manage this area.

One contract might be a bit of boundary auditing. Mutawintji had real problems with its shape and borders, but its worse for Terry Hie Hie because this Brigalow and Nandewar conservation 'area' has actually got eight pieces and each one is surrounded by neighbours, so this could be anything up to 50 neighbours. So boundary/neighbour liaison is one type of role for the co-op, then a bit of fence repair and maintenance and then some signage work, some site recording, a bit of community liaison and also some fox control and weed control. Those are the sort of things we're hoping to have contracts for over the next couple of years.

Heather: The people who are the teachers, how did they build up their knowledge of that country? Were they working up in there?

Peter: Well most of them are older people like Lou Swan or Jack Duncan, those older people who may not have been on the old settlement there before it was revoked in 1924 but who spent a bit of time out there working on properties all around. So they spent a lot of time with generations older than they were, and so they were talked to a lot. Even though the Mission had gone, there was still lots of work around there, either on the stations with sheep and cattle or a bit of farming, or in the State Forest close by. 
Heather: It's actually a really interesting dimension of thinking about pastoral labour, not just as a source of cash wages (or not!) and not only the chance to carry on with traditional cultural activities like ceremonies like we know people did in some areas. But there was ecological work that people were doing, keeping on knowing about their country, learning it, seeing it, watching it change. All that was the sort of thing that pastoral employment and pastoral access allowed people to do is now incredibly important in conservation work, or development and protection of sites and lands.

Peter: $\quad$ Even if at the worst it only provides a mirror of what not to do!

Heather: Do you think that sort of historical experience of the country gives you an idea of change. So you've got a baseline, you can talk about what was changing to get worse, as well as what might get better. But if you were not out there at all, if there had been no stock work or even domestic work on the stations, you wouldn't have been able to get any access to the country at all once the Protection Board mission had closed down.

Peter: That's right. And then there's also a few younger people who have made it their business to learn about plants and ecology or about language. Hopefully we'll get them involved as teachers, as well as the older people. So it'll be reasonably low key but also hopefully very practical. We'll keep an eye on the idea of acquiring skills that are useful for taking on works there in the Park.

\section{Aboriginal and Conservation advocates}

Heather: Over all these years you've not only been closely involved with Aboriginal communities but have taken up local issues as a member of environmental advocacy groups like the Darling River Environmental Group and others, working in campaigns to improve river ecologies and get rid of weirs on the Darling among other goals. Have you found 
contradictions between your work with Aboriginal people and the approaches that the wider conservation movement has taken?

Peter: There are lots of shared goals, but at times I've met suspicion towards Aboriginal people from conservationists of a certain ilk, who seem to have the great underdog mentality, to have an image of themselves as conservation heroes, the good guys surrounded by a sea of bad guys. This applies somewhat to the National Park Service too and its one of the reasons the Service is struggling in it's attempt to change it's attitude to Aboriginal people. Because along comes the blackfellas who...

Heather: $\quad .$. are even more the underdogs...

Peter: ... Yeah, they're the classic, they're the archetypal underdogs who by definition must be the good guys and everybody else is the bad guy. Some conservationists feel resentful that they've fought for these national parks against the outside world and then along come these people say "Hey, this is our land. Haven't you forgotten somebody?” It's a difficult change to make, when you've justified it in your own terms for so long, to feel you have to recognize that there is someone else with an interest that might be stronger than yours. So it's a threat to that very simple analysis. I think threat is the word and suspicion about where it's coming from and where it might be going to. And there is a little bit about 'us' and 'them', a feeling that Aboriginal people are 'outsiders'. that these people aren't part of us and we can't control their decisions, so if we give an inch, they might take a mile because we're not going to be there for the second inch. There's a worry about losing control over the directions of the movement.

So about two and a half years ago I tried to initiate a change to the Indigenous policy of the Nature Conservation Council, the umbrella body for all the various environmental advocacy groups, large and small, across the state of New South Wales. The old policy that was there before was conditional and just simply mean, I think. Aboriginal people would only be consulted, it said, if they fulfilled the conditions that the environment movement set, which mean they had to 'prove' that they had environmentally sound intentions! You know, it would be a terrible thing for any Aboriginal person to have to read it! They'd want to 
go outside and shoot somebody. That very personal sense of how insulting it was to Aboriginal people was what motivated me to change it most, so that at least there was going to be a policy that a blackfella could pick up and read and not be offended or alienated. They mightn't agree with it but at least they wouldn't be insulted by it.

But the attempt to change it was seen as a threat to the core values of the conservation movement. That's how it was articulated by those conservationists who resisted. It was as if they were saying: 'we fought so hard for national parks and here they were being given away to people who can’t be trusted'.

Heather: Can you explain that perception that Aboriginal people weren't able to be trusted? Was that an argument which contrasted contemporary Aboriginal people's cultural and social position as opposed to something imagined to be more 'traditional'?

Peter: Yeah, that's an interesting one. Maybe the conservationists had taken on the legitimacy of the 'ancient Aborigine' for themselves and felt that they were the ones that loved the land the most and looked after it? So perhaps they have a belief that 'the poor deculturated people who are today's Aboriginal people have basically lost it'! I think there is an element of that in there.

But there's also another factor and that is that the NCC in particular is very city dominated. So one of the problems is that the people in it, making decisions, aren't having many dealings with Aboriginal people. As you get out into the bush a bit, if you're a local conservationist then you have to be working quite closely with local Aboriginal people, all over New South Wales. And maybe those local conservationists' issues aren't all that big or, there's still a bit of tension with local Aborigines or whatever it is, and they're not making the headlines. But they're doing it. For instance, there's some interesting things happening in the Blue Mountains which is close enough to Sydney for the sort of people I'm describing to want to be involved, for the Sydney-based conservationists to be involved. And as well there's also the resurgent Aboriginal community there and they are in contact so perhaps it shouldn't be all that hard. 
I think there's a little bit of hearing what you want to hear that has been going on. But its probably been on both sides. I don't know a lot about that. But interestingly, there was one person who was at the NCC conference where my agenda item came up, which was to revise the policy to take it in the direction of positive partnerships with Aboriginal people. This person came up to me before the agenda item was discussed and I asked him what his attitude was because I wanted him to support what I was doing. He said he couldn't support it, because there was this lack of trust and, there was one instance or whatever that he could refer to, where the particular Aboriginal group or people or organisation, had gone against conservation interests, as he saw them. And I spoke to him again recently, just a couple of months after the conference and he said he'd been to a workshop with the local Aboriginal groups, where he'd had the opportunity to talk matters over directly. He felt now that he could support it much more positively. So there's this distance problem, you know, which has prevented people from having much to do with each other, that's all I'm trying to illustrate here.

Anyway, at that conference in October 2006 my attempt to change the NCC policy failed. But it will come up again and I'm sure it will change in the end.

\section{Some ways forward}

Heather: So do you feel like there are some ways forward here? We have just been talking about non-Indigenous groups who see their focus on environmental conservation but the underlying Aboriginal goals have invariably focused on ownership, in the broadest sense of cultural, social and economic values which each include an environmental dimension. Are there ways those goals can come together through park management?

Peter: Overall I think there are some positive signs for change. The National Parks Service has been trying to open up to changes at Mutawintji and there's a new Plan of Management being negotiated, which might find a way out of the sense of polarization that has come out of these years of conflict. But there are 
continuing attacks from within government and it remains to be seen whether the government will overcome these racist tendencies and give genuine full support to Aboriginal ownership. The Board can be an effective conservation manager if those issues which have been causing the polarization, like the failure to recognize the Board's power in decision-making and the failure to implement the Board's decisions, can really be addressed. Then it might be possible to develop some much more productive ways to work together.

As you say, the underlying Aboriginal goal is about getting back to the land. People will use different ways of achieving this. So at Terry Hie Hie, where the government pulled back from supporting Aboriginal ownership, the local people are trying another way. Securing their role in management first, then looking for ways to get secure, legally-binding empowerment as time goes by.

Another lesson is the one from that conservation activist from the NCC meeting who is changing his position is important too. Aboriginal people and the conservation movement have often got different starting positions. And there might be negative people who take advantage of that, to scare people or whatever, and that makes it harder to work together. But in my usual optimism, how I see it is that these aren't conspiracies or bad intentions. There's just this lack of experience that prevents us from making good coalitions. It's because we're not practiced in partnerships. We've lost the opportunities we might have had in the past to work together, when there were more rural communities for example. So now we're not practiced in negotiating and we're not practiced in seeking consensus either. But getting some practice, taking opportunities to talk and work together, might open up some more opportunities to build those real partnerships.

Aboriginal ownership of National Parks is one of the best land rights achievements in New South Wales, and it is good for conservation.

One thing is for sure, Aboriginal people will not give up. Its time for nonAboriginal people and governments to recognize Aboriginal ways of looking at the world and support those aspirations. I look forward to the day when Aboriginal ownership of National Parks is the rule rather than the exception. 